\title{
The financialization of rented homes: continuity and change in housing financialization
}

\author{
Gregory W. Fuller ${ }^{1}$
}

Received: 14 January 2021 / Accepted: 9 September 2021 / Published online: 2 November 2021

(c) The Author(s) 2021

\begin{abstract}
This paper has two purposes: the first is to offer an empirical account of how rented homes have become more entangled in financial markets over the past two decades, particularly through the advent of real estate investment trusts (REITs) and listed real estate operating companies (REOCs). The second is to assess whether conceptualizing this as a process of "rental housing financialization" - distinct from but connected to the broader concepts of "housing financialization" and "financialization" - offers value to the scholarly community.
\end{abstract}

Keywords Financialization $\cdot$ Housing $\cdot$ Real estate investment $\cdot$ Concepts

The concept of "financialization" captures the dominant trend in capitalist development - and "housing financialization" has been one its clearest and most salient manifestations - over the past 50 years. Except when purchasing with cash, the sale of a home usually requires the parallel and entangled creation of a financial instrument - a mortgage. As such, the increasingly mainstream business of lending to households has focused on the owned home. Especially since the global financial crisis at the end of the 2000s, we have seen the emergence of a different sort of housing financialization focusing on the rented home. Here, we are particularly interested in real estate investment trusts (REITs) and listed real estate operating companies (REOCs). This paper argues that there is analytical value in separating the concepts of housing financialization and rental housing financialization. Accordingly, the paper begins in the first section with a critical examination of both financialization and housing financialization as social science concepts. The second section then frames recent developments in residential rental markets as a distinct idea: rental housing financialization. The third section provides a survey of these developments across divergent local systems, while the final section concludes by arguing

Gregory W. Fuller

g.w.fuller@rug.nl

1 Department of International Relations and International Organization, University of Groningen, 26 Oude Kijk in't Jatstraat, 9712 EK Groningen, The Netherlands 
that conceptually separating the financialization of residential rentals from the moreestablished financialization of the owned home yields analytical and strategic value.

\section{Financialization and conceptualization}

Financialization is a concept that is subject to criticism, particularly concerning whether it is too ambiguous or ill-defined to offer practical value to researchers. These debates are arguably best captured by Ewald Engelen (2008), as well as Brett Christophers (2015) and Manuel Aalbers (2015) in dialogue, who collectively present a nuanced view of a concept with problems - but also with potential utility.

There is no doubt that financialization can mean a great number of things - so many that any effort to cover all of its meanings in would run a serious risk of incoherence. As Christophers notes, there were already at least 17 different meanings assigned to the term financialization by the end of the 2000s (Lee et al. 2009) - and more have proliferated since. Even those more positively disposed to financialization as a concept readily concede this point: financialization means a lot of different things. Moreover, its history as an idea can be narrated in different ways. Some trace the concept back to Giovanni Arrighi (1994), others prefer citing Magdoff and Sweezy (1987), and one could argue that the appropriate place to start the discussion is with the (disparate) early twentieth century contributions of Rudolf Hilferding, RH Tawney, Adolf Berle, and Gardiner Means.

This paper follows Aalbers $(2015,216)$ in arguing that the primary value of financialization is in connecting "different disciplines but also different levels of analysis, from the very micro to the very macro - and demonstrating how they are related." That is, it has value as an umbrella term reminding us that, while studies of financialization might examine very different subjects in very different ways, they remain part of a broader whole. This value is reflected in the two most oft-cited definitions of financialization, the first from Aalbers $(2017,544)$ building on an older — but broadly very similar — definition offered by Gerald Epstein (Epstein 2005, 3):

I define financialization as "the increasing dominance of financial actors, markets, practices, measurements and narratives, at various scales, resulting in a structural transformation of economies, firms (including financial institutions), states and households"

financialization means the increasing role of financial motives, financial markets, financial actors, and financial institutions in the operation of the domestic and international economies.

As Aalbers himself notes, these definitions need to be refined in order for operationalization in any specific context; however, their comma-laden inclusive phrasings capture the multifaceted family resemblances that hold the financialization literature together. Yet, this begs the question of whether tying together such distinct ideas is of value in the first place.

For Aalbers - and for your present author — the answer is yes. Many of the scholarly communities engaged with financialization struggle with communication 
across disciplinary, sub-disciplinary, methodological, and ideological boundaries. Human geographers, sociologists, anthropologists, political economists, economists, and housing specialists all discuss ideas that would fit under the umbrella definitions above. However, these communities struggle to understand and cite one another and often fail to recognize that they are carrying on closely related conversations using slightly different conceptual frames. The same occurs within fields across functional lines: one political economist might be focused on how financialization works for non-financial firms while another political economist does the same for households, and another for the state. Arguably most importantly, financialization bridges multiple levels of analyses: the financialization of individual life cannot be considered wholly separate from efforts to understand financialized accumulation regimes and intermediate-level theories concerning institutional actors such as banks or businesses or households connect to both the micro and macro levels.

Ultimately, the fundamental value of financialization as a concept stems from these linking functions. By classifying discrete processes as financialization and linking them together within a unified concept, we effectively engage in what Alexander Wendt (1998) would describe as constitutive explanation. The act of classifying a thing as financialization calls into being an understanding of modern society in which the rising salience of finance and financially mediated social relations play central roles.

\subsection{Housing financialization}

Such a broad definition would be impossible to operationalize in a single way because it encompasses a multitude of interrelated processes. The key task for a scholar writing on financialization is therefore to indicate which of these processes they are investigating and how they link it to the broader whole. Of particular interest here is financialization as it pertains to the home. This could be defined by using the Aalbers definition above with an emphasis on housing specifically. Another good definition specifically intended for this purpose comes from the UN Human Rights Council $(2017,3)$ which defines housing financialization as:

[S]tructural changes in housing and financial markets and global investment whereby housing is treated as a commodity, a means of accumulating wealth, and often as security for financial instruments that are traded and sold on global markets. It refers to the way capital investment in housing increasingly disconnects housing from its social function of providing a place to live in security and dignity.

Through the early 2010s, most of the research into housing financialization revolved around homeownership. While certain aspects of contemporary housing financialization can be traced back to the advent of mortgage-backed securities (MBS) in the USA or even the earlier development of covered mortgage bonds in Northern Europe, the explosion of interest into housing financialization typically coincides with the expansion of the 1980s' housing bubbles, their bursting during the 1990s, and reemergence in the early 2000s. Reflecting the linking value of the 
financialization concept, this era of housing financialization cannot be understood without the broader context of banking deregulation, international capital flow liberalization, collapsing interest rate controls, and welfare state retrenchment across the developed world. Even though many of the instruments at the heart of housing financialization had existed for decades, it was not until the 1980s that a combination of factors accelerated the process of integrating housing wealth into mainstream financial markets. Much of the early literature in the field of housing financialization was thus centered on teasing out the causes and consequences of the transformation underway - with particular emphasis on rising precarity and broader macroeconomic instability (c.f. Aalbers 2008, 2017; Aalbers and Christophers 2014; Fuller 2016; Fuller 2019).

Like financialization itself, the value of housing financialization is that it functionally connects similar scholarly discussions across different academic communities. The value of this linkage is perhaps most evident when looking at works that could be part of the financialization literature but are not generally thought of that way. This is particularly true in mainstream American economics - likely due to the baggage of heterodoxy associated with a term devised by Marxists. Thus, scholars such as Atif Mian and Amir Sufi (2014; 2018) essentially engage in work that very clearly sits under the financialization rubric - even drawing many of the same conclusions - but do not use the term. Similarly, the emergence of the "safe assets shortage conundrum" within economics is closely related to why capital has tended to reach out and integrate new classes of financial assets (Caballero et al. 2017) but this is generally not considered part of the financialization literature. The lack of interactions between these different communities has arguably weakened them all - the economists do not cite the sociologists and human geographers, who in turn rarely cite the orthodox economists, leaving us all the poorer for it.

The final section of this paper will return to lessons we have taken from the housing financialization literature in order to assess whether these lessons are modified at all by considering not just the financialization of owned homes, but the financialization of rented homes as well. That is, what explanatory value is offered by setting rental housing financialization aside as a concept unto itself? It is to this question that we now turn.

\section{Rental housing financialization}

The first generation of housing financialization research focused extensively on mortgage markets and homeownership, as it was these assets that were integrated into increasingly globalized financial markets at the end of the twentieth century. It was not until the 1990s - accelerating through the first two decades of the twentyfirst - that residential rental properties were subjected to the same process.

Gertjan Wijburg (2018) separates this into two distinct periods. The first, which he calls housing financialization 1.0, refers to the late-1990s and early 2000s entry of private equity firms into the market for multi-family residential (MFR) property like apartment blocks and towers. In this phase, financial firms would buy up large properties and hope to sell them to realize capital gains - effectively engaging in 
house "flipping" on properties too large for retail speculators. As housing markets across developed economies crashed toward the end of the 2000s with the onset of the financial crisis, these actors exited the market and sold their physical buildings to other institutional investors. In particular, a large number sold their asset portfolios to the newest actors in town: REITS and listed REOCs.

Residential REITs and REOCs share two basic traits: (1) they primarily own residential real estate and derive most of their income from rent or property sales, and (2) they are publicly listed on an exchange. The two structures differ on a third criteria: REITs are "pass-through" entities built to distribute the vast majority of their profits to shareholders in the form of dividends; listed REOCs are ordinary corporations and can more easily reinvest profits into their operations. This arrangement means that REITs do not have to pay corporate tax on their own earnings; rather, those earnings go straight to shareholders who then pay the required taxes. REITs can accrue investor fees and manager salaries, retaining a small portion of their rental incomes, in exchange for pushing virtually the entire tax burden of their holdings onto the end investors.

Both REITs and listed REOCs have tremendous benefits for end-investors, despite their assuming the tax burden in the former case. This is especially true of smaller investors who would otherwise struggle to access these revenue streams. A financial market participant buying a share in a REIT or REOC does not have to buy an entire apartment tower (i.e., a large chunk of illiquid, undiversified, physical property). Instead, they can buy a slice of the income generated by a number of different properties, safe in the knowledge that it is much easier to get rid of a liquid financial product than it is to get rid of a physical building. Furthermore, the hassle of actually owning, letting, and maintaining physical property is handled by the REITs and REOCs themselves.

This sort of company has existed since the mid-twentieth century; however, they are relatively new to the residential market (EPRA 2017). Most existing REITs do not own homes at all, instead holding office and retail space, industrial infrastructure, healthcare facilities, mobile phone towers, and even data centers and timberlands. Belgium, for example, has the second-oldest REIT structure in Europe, and non-residential REITs own about half of all office space in Brussels - but less than 1\% of housing (Romainville 2017; Marzuki and Newell 2019).

Despite their obscurity, REITs and REOCs were well-positioned after the financial crisis of the late 2000 s - and again during the Covid-related downturns (Morwa 2020; Strauss 2020; Corcoran 2020) — to expand into residential markets. While listed real estate firms do earn income by selling their properties (as was the case with financialization 1.0 firms), this is not their chief goal. Rather, REITs and REOCs market themselves as providing sources of income insulated from the business cycle in the form of rents. Their investor presentation materials emphasize high occupancy, reliable tenants, quality locations, and low turnover of properties - essentially promising reliable returns even during bursting housing bubbles or international slowdowns in economic performance. If hedge funds went into MFR real estate engaged in the risky business of what Keynes called "speculation" (i.e., seeking capital gains by guessing where the market would go next), REITs and REOCs are engaged more in the more sober business of "enterprise" (i.e., seeking 
income-like returns on a longer-term investment). This, not incidentally, makes REITs and REOC shares look far more attractive to the glut of global savers driving Caballero et al.'s "safe assets shortage."

Freed from the pressure to predict where capital gains will be highest, REITs and REOCs focus on achieving profitability through longer-term cost-cutting and revenue maximization. Cost reductions are typically achieved through economies of scale, with large regionally focused landlords able to use their size to reduce maintenance and upkeep expenses (though simple disregard for maintenance and upkeep have also been evident in cases). There are a number of different strategies in use to raise revenue, from divesting older properties and using the proceeds to develop or purchase newer higher-return properties, to aggressively raising rent in deregulated rental markets, to making property upgrades that can be used to justify rent increases even under controls.

The specific structures of listed real estate entities can vary a great deal - even within a relatively defined category like REITs. Some REITs are not publicly traded; others operate through holding mortgages on properties rather than owning properties themselves. We are focused here on the integration of rental properties into financial markets as equity-like instruments, which means that we are focusing specifically on listed REOCs and equity REITs focused on residential real estate. Even with these restrictions on scope, we are talking about major actors: REITs now dominate the ranks of the largest landlords in the USA (NMHC 2020) and Canada (August 2020) — and Germany-based REOC Vonovia is the single largest corporate landlord in Europe, owning over 400,000 homes.

\subsection{The illuminating but confusing tale of Vonovia}

Indeed, Vonovia provides a useful mini-case to illustrate what the current era of rental financialization looks like — both in comparison to rental financialization 1.0 and in seeing what a non-financialized alternative might be. The bulk of the properties currently owned by Vonovia began their lives as publicly owned homes intended for employees of Deutsche Bahn, the German state railway company. During the height of German triangulation politics under Gerhard Schröder, these properties were sold off as part of a push toward broader privatization of Deutsche Bahn. The initial buyers of the properties were a pair of private equity firms (Nomura Holdings in Japan and Terra Firma in the UK) which had previously set up Annington Homes to buy up government-owned residential property from the British Ministry of Defense in the late-1990s. They then repeated the process in Germany, forming a firm called Deutsche Annington (Korthals Altes 2019).

The firm continued to buy state-owned housing assets, particularly the stock once owned by the state utility VEBA, as well as smaller portfolios. After the credit freeze of the late 2000s and related housing bubble collapse, the firm diversified its funding sources by going public, converting itself into a publicly listed REOC, eventually becoming the first real estate company included in Germany's DAX index. In 2015, Deutsche Annington merged with Luxembourg-based GAGFAH — itself largely owned by US-run private equity firm the Fortress Investment Group - to 
form what is now called Vonovia. Reflecting the shift away from private equity and toward savers seeking "safe" assets, the firm's two largest shareholders are now BlackRock - a major US firm focused on fixed-income investment - and the central bank of Norway (i.e., the end investor is the Norwegian sovereign wealth fund) (Vonovia 2020a).

Over 30 years, a home that might have once been owned by the German state for the purpose of housing state employees (non-financialized rental housing) has been sold to a private equity firm hoping to resell the property for capital gains (rental financialization 1.0), only to watch capital for such acquisitions dry up, leading them to sell shares in the income streams generated by that property through organized exchanges (rental financialization today via listed real estate firms). Moreover, while Vonovia is not formally a REIT — there is an alternative "G-REIT" structure available in Germany, which places more restrictions on the firm - it is generally discussed alongside REITs as a comparable structure and is included in the global index of REITs provided by NAREIT, an industry group representing REITs.

\section{Listed real estate around the world}

Vonovia is just one prominent example of a whole new listed equity ecosystem in global housing markets. REITs have existed as a specific structure since their first creation in the USA in 1960, with the Netherlands, New Zealand, and Taiwan following shortly after (1969). These early entities were focused on commercial rather than residential property. It was not until the twenty-first century that REITs accelerated their expansion globally and into MFR properties as well as portfolios of single-family rental (SFR) homes. Most major economies - Japan (2000), France (2003), Germany, Italy, the UK (2007), Spain (2009), Mexico (2010), India (2014), and Saudi Arabia (2016) - adopted US-style REIT structures in the past two decades, with China actively investigating them as of writing. All told, REITs are specifically available in about 40 countries globally, accounting for about $\$ 3.5$ trillion in total value - with the largest concentrations in the USA and Japan. Most of that accrued after 2000, with the total (including non-residential) US REIT market valued at a modest $\$ 139$ billion at the turn of the century (Nareit 2020).

Looking at residential REITs and listed residential REOCs together, their expansion has been a product of the post-financial crisis era. As noted previously, this was partly due to the crisis itself: private equity firms and hedge funds wanted to exit the market entirely as distressed homeowners sold property or were foreclosed upon and the prospect of capital gains dimmed. Both REITs and REOCs often stepped in as buyers of these properties. Funds continually merged and absorbed one another, leading to a bewildering array of rebranding exercises - as with the case of Vonovia. Indeed, reading even very recent academic articles about these entities often involves sleuth work to determine which names had been changed and who now owns whom.

The global expansion of the market peaked in 2019 before taking a Covid-driven downturn. Even so, global property advisors Savills declared, "once considered alternative, operational residential has become a mainstream investment asset class 
and the defensive benefits of investing in beds are set to continue" (Roberts and Tostevin 2020, 2). Many investor presentations published in 2020 made reference to this: they see continuing uncertainty as ensuring demand for rental housing, particularly among knowledge economy workers not looking to purchase a home. Going deeper than these broad characterizations requires a more regional perspective:

\subsection{The USA}

The United States was the innovator and chief evangelizer of the pass-through REIT structure, following a long history of housing financialization on the ownership side. Its 22 residential REITs are the largest and most varied in the world, though many of the most significant ones pursue similar strategies. Equity Residential (no. 2), AvalonBay (no. 3), Essex Property Trust (no. 10), Aimco (no. 21), and United Dominion Realty (no. 22) are all among the 25 largest landlords in the country, collectively owning approximately 300,000 homes and generally pursuing similar business strategies (NMHC 2020). They are all primarily focused on accumulating high-quality A- and B-grade properties in established high-income coastal metro areas rich in knowledge economy jobs like New York, Boston, Washington DC, Los Angeles, and San Francisco (Jensen 2018). In their investor materials, these REITs showcase the high standards of their properties and the financial reliability of their higherincome tenants.

A related group includes Mid-America Apartment Communities (MAA) - the largest residential landlord and REIT in the USA - as well as smaller firms like BlueRock Residential and Camden Property Trust. These pursue very similar strategies to the above but with a different geographical emphasis. Instead of clustering in high-cost coastal urban locales where rental regulations are more common, they are focused on lower-cost and regulation-favorable areas across the Sun Belt, where the knowledge economy is growing rapidly. This group of metro areas includes Phoenix, Las Vegas, Texas' major cities, Nashville, Atlanta, North Carolina's "Research Triangle," and much of Florida. The lower population densities of these areas also mean that SFR REITs that let out whole standalone homes, such as American Homes 4 Rent (AH4R) and Blackstone-backed Invitation Homes, are also active. These SFR landlords also position themselves as an option for higher-income tenants, and their customer base tends to be older and includes more families looking for larger properties in suburban areas, with good transport links and schools.

Both of these groups of funds invest in higher-end properties near "high-quality employers" in both suburban and urban areas (Amazon, Facebook, and Google are all explicitly mentioned in multiple investor presentations) - in particular, where newbuilds with quality amenities or property upgrades bring in higher-income tenants who can sustain larger rent increases (Equity Residential 2020). This group of trusts, focused on leveling up residential properties in desirable areas in order to attract a higher-income clientele, is the prime drivers of concerns over gentrification.

Several of these firms have notably poor public reputations. Equity Residential, often cited as a major cause of urban gentrification, is currently the defendant in a class-action lawsuit over the use of stiff late-payment penalties allegedly 
being used to push regulated renters out of units so they could be replaced with higher-income tenants (Wotapka 2012). Invitation Homes and AH4R are similarly defending themselves in more than a dozen class actions related to overly aggressive use of late fees as well as insufficient maintenance practices (Semuels 2019; Anderson 2019). Equity founder Sam Zell is a particularly hated figure among housing advocates, due both to Equity's corporate behavior and Zell's personal bankrolling of campaigns against progressive housing measures such as rent controls (McDonald 2020).

Indeed, fears over statutory rent controls or requirements to provide affordable housing make relatively frequent appearances in these firms' materials. Aimco (2020), for instance, projects that it will be winding down its investment in the traditional high-income coastal centers in order to reallocate its portfolio to more deregulated jurisdictions. Similarly, UDR $(2020,22)$ trumpets its ability to lobby governments to oppose housing regulation, "enabling our surgical approach toward pricing apartment homes." In investor materials, these companies explicitly describe progressive housing policies as threats to their business models and spend substantial sums of money ensuring that rent-control regulations such as California's Proposition 10 (2018) and Proposition 21 (2020) go down to defeat.

There are some smaller groups more explicitly focused on providing midmarket options, achieving cost savings by targeting smaller metro areas or accumulating and upgrading older B-class properties. These include Investors Real Estate Trust (IRET), Independence Realty Trust (IRT), Front Yard Residential, and BSR. However, even among these more cost-conscious landlords, there is still a clear emphasis on chasing the same tenant demographic: younger, higherincome, professional workers looking for a quality mix of amenities and location. While described as mid-market and found in sleepier communities, these properties nevertheless often sit within gated communities, offering swimming pools, fully equipped fitness centers, and other shared recreational facilities. If not contributing to the sort of urban renewal generally thought of as gentrification, these investments nevertheless give the impression of investment resources being driven to relatively high-end options.

Ultimately, among existing publicly traded residential REITs, the most affordable housing owned by REITS is manufactured homes (i.e., trailers and RVs) and their communities - Sun Communities, Equity Lifestyle Properties, and UMH Properties. While unambiguously serving lower income tenants, these firms also engage in controversial practices, some of which are enabled by the dissociation between ownership of a manufactured property and ownership of the land under that property. That is, these entities focus on owning the land and providing communal services, while the homes themselves can also be rented or owned, and can be physically brought from elsewhere. Sun and Equity have been cited in lawsuits over practices related to the confiscation and removal of such homes - sometimes without adequate notice (FMO 2019). Additionally, a jury found Equity Lifestyle — also founded by Zell — liable for \$111 million in damages over poor maintenance at its California Hawaiian Mobile Estates (Kaplan 2014). 


\subsection{Europe}

Annual investment in European MFR property, which had peaked in the pre-2008 period below $€ 20$ billion, reached nearly $\$ 60$ billion by 2019 , with the Covidaffected first quarter of 2020 outpacing even the record pace in $2019 .{ }^{1}$ As in the USA, these flows are disproportionately directed toward a small number of dynamic and wealthy metro areas. In declining order of investment volume, the leaders in absorbing MFR investment flows between 2014 and 2018 were Berlin, Copenhagen, London, Amsterdam, Stockholm, Hamburg, Madrid, Frankfurt, Munich, and Dublin (CBRE 2019; Stachen 2020). To this, we can add a number of higher-income university cities that attract internationalized student housing specialists like Belgian REIT Xior Housing.

Given national regulatory differences, there is a more diverse set of REIT and REOC firms in Europe. Even so, there are some additional parallels to our descriptive exploration of the American environment. Ireland's largest residential landlord is its one residential REIT — the fittingly named Irish Residential Properties REIT (I-RES) - which operates similarly to the US REITs in wealthy coastal centers. It owns 3700 newer high-end properties almost exclusively in the Dublin metro area and intended for rent to professional tenants (Irish Residential Property REIT 2020). Given that this one firm has defined the Irish residential REIT experience, it is perhaps not unsurprising that Richard Waldron (2018) grew concerned that REITs in Ireland would contribute to inequality and the subordination of local preferences to the demands of internationalized capital on a hunt for yield. Similarly, French REIT Gecina has embraced a strategy of investing in areas of "scarcity and centrality" almost entirely in Paris (Gecina 2019).

The largest source of listed residential real estate assets in Europe is Germany, where Vonovia (no. 1), Deutsche Wohnen (no. 2), and LEG Immobilien (no. 4) are each among the five largest real estate funds of any description in the whole of Europe. Vonovia is explicitly trying to reduce exposure to peripheral areas in favor of urban regions such as the Randstad conurbation, the Ile de Paris region, Vienna, and Sweden's major cities. Key to Vonovia's strategy is the renovation of its properties. This is particularly important in Germany, where making capital improvements is essential in order to raise rents beyond market rates. While rent increases in Vonovia's properties were only marginally higher than the market average in 2013, modernization-tied rent hikes drove that to more than double the market average by the end of the 2010s (Vonovia 2020b). Deutsche Wohnen pursues a similar strategy on its roughly 165,000 homes mostly in and around Berlin, while LEG Immobilieren is specialized in the wealthy state of North Rhine-Westphalia, emphasizing growing metro areas and university towns rich in (again) knowledge economy jobs.

Germany is unusual among developed countries in that long-term tenancy is one of the most common forms of housing tenure, and many people rent by choice. This, combined with the low cost of investing in real estate in booming areas such

\footnotetext{
${ }^{1}$ France is excluded from this as CBRE does not collect French data - though the Ile de France region is one of the largest target markets for REIT and REOC investment.
} 
as Berlin, has contributed to an explosion of investment and construction activity. Foreign REITs have gotten in on the action, with the residential holdings of French REIT Covivio (itself the 9th-largest REIT in Europe) held almost entirely in Germany. Most recently, the largest German inflows into MFR have been from Norwegian institutional investors (JLL 2020). As noted earlier, this intense activity extends to mergers and acquisitions. In 2016, Vonovia failed to complete a hostile takeover of Deutsche Wohnen, though it did succeed in scuppering Deutsche Wohnen's own attempt to absorb another fund, LEG (Jones et al., 2016). The contentious takeover attempt collapsed over concerns that Berlin would not be able to sustain the sort of rent increases investors had hoped for — not least because the Berlin government is prone to interfere through rental regulations.

There are some examples of European residential REITs that do not emphasize higher-end property in growing metro areas and, perhaps surprisingly, they are clustered in the UK. The largest British REITs are not focused on residential property and those that are tend to be smaller and more specialized. In fact, a failed attempt by Harwood Capital to set up a high-yield REIT invested in British residential property suggested that appetite for MFR REITs is not boundless, especially in places where MFR property is already extremely expensive, as in London. After announcing an initial public offering, the prospective trust failed to attract enough interest from institutional investors and was scrapped, returning initial investors' money (Lumsden 2018).

Instead, the most substantial residential REITs located in the UK are far more niche. Some have invested predominantly in housing for retirees (KCR Residential and Residential Secure Income), others in university housing (GCP Student, Empiric Student Properties, the Unite Group), and two substantial REITs have focused on housing for disabled people with substantial need for living assistance (Civitas Social Housing and Triple Point Social Housing). Retirement and student homes are seen as less exposed to normal business cycle fluctuations and - especially in the case of student housing — benefit from localized monopolies in supplyconstrained areas like central London. The two social housing REITs are among the most aggressive in marketing the ethics of their business models. This specific class of housing is exempted from wider rent controls in social housing because developing and maintaining them is particularly capital-intensive. Moreover, these REITs generally do not let directly to social housing tenants; rather, they partner with local government or private healthcare providers who then provide the housing to residents, limiting exposure to market fluctuations.

\subsection{East/Southeast Asia}

Outside of the USA, parts of East and Southeast Asia have been the most enthusiastic adopters of REITs, with an especially well-developed market for residential REITs found in Japan. Japanese REITs are more heavily residential - with residential REITs making up 18 percent of total REIT market capitalization - than anywhere in the world, higher even than the USA (14 percent). These holdings are held by a fluctuating number of around 10 Japanese REITs (J-REITs) whose size has 
collectively expanded from roughly $\$ 300$ million in 2006 to over $\$ 20$ billion by the end of the 2010s (Lin et al., 2019).

Residential J-REITs are very similar to each other - and to what this survey has identified as a core approach to REIT investment. All are overwhelmingly concentrated in Tokyo, Osaka, and Nagoya, with metro Tokyo accounting for the vast majority of all assets. Advance Residential Investment Corporation, the country's largest residential REIT, describes its strategy as investing in all types of housing, with an emphasis on smaller and newer "prime" properties intended for rent by office workers, especially two-income childless households. Comforia Residential REIT, Nippon Accommodations, Sekisui Housing, Kenedix Residential, Starts Proceed Investment Corporation, Samty Residential, and the residential components of Daiwa House REIT all fit within this broad approach — an assessment that closely echoes Natacha Aveline-Dubach's (2020) findings on residential J-REITs.

East Asian real estate more widely has become a more popular destination for post-financial crisis capital flows. Insurers such as France's AXA and Germany's Allianz, together with predominantly Asian pensions and sovereign wealth funds, are the largest contributors of these flows, seeking to indirectly invest in real estate as part of their broader portfolios (Lin et al., 2019). Most recently, the Covid pandemic has incentivized more defensive investments in "safe havens" such as prime Japanese real estate (Liu et al., 2020).

REITs and listed real estate are also well-established in Hong Kong, Singapore, and Taiwan, with Hong Kong's Link REIT being the oldest and largest in Asia as well as a highly controversial encourager of gentrification (Huang 2010; Yuen 2016). However, residentially focused REITs in these countries are less common, and a large share of publicly listed real estate is held outside formal REITs. A noteworthy example, and helpful reminder of the multidirectional nature of capital flows in this area, is Singapore's Ascott Residence Trust. It owns properties spanning 39 top urban areas in 15 countries throughout the developed world, predominantly in serviced properties intended for wealthier travellers and term accommodation for professional workers (Ascott Residential Trust 2020).

Finally, China already sports a listed real estate sector worth $\$ 600$ billion, though REITs are only beginning to appear as formal structures (Chong 2019; Bloomberg 2020). A cluster of younger Chinese scholars working in urban studies reflect this interest - with a special emphasis on using REITs to encourage the construction of more "affordable" housing (Huang 2010; Hueang 2019).

\section{Continuity and Change in Housing Financialization}

Thus far, we have set up rental housing financialization as a separate aspect of financialization, linked to the whole - especially to housing financialization - but distinct in important ways. But how does that help us understand the relationship between finance, housing, and society? Ultimately, the value of this paper hinges on the claim that it does - and that the concept helps us explain something. While there are clear parallels to the financialization of owned homes, there are also key 
areas where the financialization of rented homes operates differently and should be expected to lead to different consequences.

\subsection{Continuity}

The most substantial commonality between financialization of the owned and rented home is the persistence of a generalized trend modified by substantial variation across local systems. Martine August (2020, 2), building off of Aalbers (2017), refers to this as a pattern of "hegemonic but also variegated" change.

This pattern results from contradictory realities at the heart of housing financialization in all its forms: real markets for housing remain highly localized but financial markets for housing-derived assets are increasingly globalized. Most homes are not internationally mobile, nor are most people. As a result, local conditions such as mortgage regulation, rent controls, tenants' rights, wage protection, and bankruptcy procedures continue to reflect jurisdictional divergence in institutions, culture, history, and ideals. Once housing assets are converted to financial products, however, they become integrated into global capital markets and are increasingly subject to homogenizing forces. This is arguably most evident in the increased synchronization of global housing prices (Alter et al., 2018) in major urban centers where most REITs and REOCs focus their activity. So, while it is impossible to talk of a global real estate market (Hilbers 2020), it is possible to talk of a globalized market for real estate-derived financial products.

Connecting the pool of global capital to locally distinct housing markets requires instruments that bridge the gap between the global financial system and local property markets. In the case of financialized homeownership, MBSs, covered bonds, collateralized debt obligations (CDOs), and credit default swaps filled this role. Each of these instruments helped mainstream savers - pension and insurance funds, banks, sovereign wealth funds, and wealthy individuals - gain access to capital income in the form of mortgage payments. REITs and listed REOCs serve an analogous purpose on the rental side of the market: they enable mainstream savers to gain access to capital income in the form of rent payments. The two sets of instruments both lower the entry costs of investing in real estate, generally improve access to real estate-derived products, and allow for diversification which can insulate the end-investor from risks of non-payment.

This dynamic, whereby housing assets are brought into mainstream financial markets as a source of income and a store of wealth, brings us back to the value of financialization as a concept. It helps remind us that we are talking about one part of a much larger picture, in which the integration of housing into financial markets is driven by other aspects of financialization (such as the shifts toward liberalization, deregulation, and greater corporate savings and financial activity). In this regard, rental housing financialization represents a slightly different mechanism for what is - broadly speaking — analogous to the function of mortgage-based financialization.

A second commonality between the financialization of tenancy and homeownership is the degree to which financial innovation is presented as a sort of panacea 
for social ills. The unrealized and retrospectively ironic promise of mortgage securitization was that it would drastically reduce the risk of default and related economic turbulence. This is another area where we can see the links to the broader financialization story. Former Chairman of the US Federal Reserve, Alan Greenspan (2000), argued toward the end of his tenure that the process of financial innovation had essentially ended postwar business cycles as we had known them - moving us into what became known as the "Great Moderation." The technical construction of housing-anchored financial derivatives was a crucial example of the great promise of financial innovation (Hellwig 2009). As each of these promises have proven ephemeral, some new candidate appears.

So it happens that while expectations of securitization have been tempered, advocates for listed real estate make even bolder claims about their social utility. One 2018 report by accountancy firm Grant Thornton was simply titled, "REITs as a force for good" (Stannard 2018). In the UK, for instance, the Civitas Social Housing REIT $(2019,12)$ trumpets its inclusion on lists of how to "make money morally" through investing in the social housing sector - claims echoed by another British firm, the Triple Point Social Housing REIT. A particularly common claim across the globe is that entities like REITs can solve housing crises by filling a need for ostensibly affordable housing, "help[ing] increase the supply of affordable housing while potentially receiving positive tax benefits and risk-adjusted returns" (Brumer 2019, para. 2).

As was the case with the ostensible benefits of financial innovation in general or the development of securitized mortgages in particular — there are reasons to doubt this happy story where rental financialization is concerned as well. The primary concern expressed by more skeptical observers is that REITs and similar structures might direct capital in such a way that serves the needs of capital while leaving the needs of more vulnerable communities unmet - as discussed below (August and Walks 2018; Waldron 2018; Lima 2020; August 2020).

\subsection{Change}

There are also at least three substantive differences that emerge when focusing specifically on rental housing financialization: (1) whereas the financialization of homeownership has radically altered demand for housing, there is some reason to expect the financialization of rented homes to alter supply; (2) the transparency of listed instruments like REITs and REOC shares is far higher than the transparency of instruments more associated with owned homes, particularly MBSs and CDOs; (3) financialization alters a tenant's relationship with their home less than it affects the owner's relationships with their property. These three differences make the strongest case for the utility of different conceptualizations of how financialization affects the home.

There is some reason to expect that rental financialization can expand the supply of housing, potentially easing housing crises. This cannot be said about the financialization of owned homes - and points at one area where the broad promise of financialization may have some genuine appeal from a progressive 
standpoint. With mortgage-lending, the participation of financial firms in the markets acts to boost demand for housing: people who do not possess sufficient funds to buy a home outright (i.e., most people) can now borrow funds from a third party, requiring them to only raise a small percentage of a home's purchase price. This pushes housing prices up as more buyers are brought into the market via increased financial access. There may be some eventual growth in housing supply as builders recognize the greater profits on offer - but it is not directly incentivized and might be opposed by existing homeowners.

The incentives work out very differently for financialized landlords, who want to maximize their number of units and tenants - especially if those properties are geographically clustered - to benefit from economies of scale. This means that while financialized landlords will clearly be looking for ways to increase perunit rent (i.e., raising prices), they are also incentivized to create more units in the first place - necessarily mitigating some upward pressure on prices. However, the incentive to boost housing supply only operates in markets that offer strong returns. This contributes to the worry mentioned earlier: that purchases by listed real estate firms directly contribute to gentrification, pushing lower-income tenants out of areas targeted for development even as the local housing supply rises. This is reflected in how many listed real estate firms focus on what is sometimes called "workforce" housing — that is, housing that serves people earning between 80 and $120 \%$ of the local median income. While described as "affordable," such housing is not affordable to large sections of the workforce, leading to some controversy over the use of the term (Ford and Schuetz 2019).

A second major difference between the financialization of owned versus rented homes is that listed rental real estate is a leap forward for transparency. The key difference is in the availability of information about the physical properties underlying the financial product: it is far easier to see the actual building you are purchasing a claim to when buying a share of a REIT or REOC than it is when purchasing an MBS or CDO. Indeed, obtaining information about the underlying properties at the heart of a securitized mortgage before the global financial crisis was so difficult that there is a bestselling book - and movie - entirely about the few (very wealthy) people that managed to do it (Lewis 2011). This was, of course, one of the most remarked-upon aspects of the housing bubble and subsequent collapse: so much so that financial literacy and improved disclosure rules have become near-universal policy responses to the broader rise of financialization.

In comparison, REITs and REOCs sport a comparatively high degree of transparency about their underlying assets. This is due in part to the listed part of listed real estate: unlike the less-regulated over-the-counter nature of mortgage derivatives, REITs and REOCs must meet more stringent corporate disclosure rules implemented by the exchanges themselves. More than that, the funds advertise themselves to investors by selling the physical characteristics of the underlying property. That is, investors buy shares in REITs and REOCs partly based on their assessment of the financial performance of the fund and partly based on their assessment of its properties - an alignment between real and financial actors which exists with rental financialization to a much greater degree than with conventional MBS. At the very 
least, this alignment of interests might be expected to generate less market volatility

— though there is no reason to expect tenants to benefit.

Thirdly and related to this last point, tenants' relationships with their homes is far less modified through financialization than the relationship between purchased homes and indebted homeowners. There is a substantive difference between obtaining and owning a physical home outright (i.e., ownership without a mortgage, through mechanisms like inheritance) and possessing the junior claim to the value of the home (i.e., ownership with a mortgage). Referring back to linkages with the "big" definition of financialization, any development that further increases homeowners' reliance on mortgages will invite more financial forces into their daily lives (Martin 2002). It will also have manifest impact on the sort of terms available to both buyers and sellers.

However, this is not the case with rental financialization - at least not to the same extent. There is no new third party — akin to the mortgage lender — with its own financially derived preferences that might be divorced from those of both buyers and seller. Unlike mortgage-lenders, the newly introduced third party to the transaction in this case (the shareholder) has interests broadly similar to the prefinancialization owner. While some pressures on the landlord might substantively change - especially when considering which buildings to buy and where - the relationship between landlord and tenant remains relatively unchanged. In cases where a property management company is used, a tenant might not even realize as their home is passed from family ownership to a private equity firm to a REIT. In each case, the reciprocal responsibilities between tenant and landlord are determined outside financial markets — and are generally mediated heavily by the state.

Of course, this is not to say that the financialization of MFR properties has no impact on housing market outcomes - that would invalidate this whole endeavor! Rather, the most substantial consequences of rental housing financialization alter the relationship between real estate companies, local authorities, and shareholders while leaving the existing landlord-tenant relationship largely in place. Rental housing financialization still renders housing more subject to the demands of financial markets, even if tenants are partly insulated from this by virtue of their own precarity. As with the earlier explosion of mortgage finance, rental financialization constitutes a new frontier for mainstream financial actors, bringing them into new spaces. In that sense, it is still financialization - and certainly falls within the concept of housing financialization. Nevertheless, rental housing financialization appears different in ways which justify its existence as a separate idea within the universe of financialization concepts.

\section{Conclusion}

On a practical level, what then does the existence of rental housing financialization imply for housing shortages, prices, and volatility?

The impact on the market for sold homes is likely to be minimal in the short term. Most rental financialization is oriented toward larger housing blocks rather than single-family units. Conversely, mortgage-driven financialization of homeownership 
is more concentrated in single-family units. The limited substitutability between a rented apartment and a purchased detached or semi-detached home insulates these markets from each other to a certain degree. However, over longer time horizons, it is reasonable to expect that housing shortages (or shortages of housing at affordable prices) may fuel more demand for rental property. Conversely, it is plausible that rapid growth in the availability of quality rented homes may have a depressing effect on prices for purchased homes.

However, rental housing financialization should have a major impact on the distribution of rental housing availability - especially in those dynamic local economies targeted by REITs and REOCs. Given their investment strategies, listed real estate appears certain to boost the supply and quality of housing intended for relatively well-educated workers earning around the median income. For this slice of the workforce, the effect of rental financialization may well be increased availability and affordability of quality urban housing.

There may be fruitful connections here to Thomas Piketty's (2020) Capital and Ideology in that we can identify beneficiaries of REIT-and-REOC-driven housing provision within multiple elite groups. As we have established, these funds prefer to provide for asset-poor but education-rich urban professionals, especially in their younger years. Furthermore, asset-rich elites also benefit from the integration of a new class of assets into mainstream financial markets, while limiting any downside that might come with increasing the supply of single-family properties. From an elite perspective, this may be close to a rare win-win in housing policy.

For renters who lack both human and physical capital, there is far less cause for optimism. Not only are many of these people too asset-poor to climb the housing ladder, they are too precarious as workers to appealing as tenants to REITs and REOCs. Worse, the expansion of higher-quality urban housing often results in the removal of existing property serving these poorer communities. In short, absent major efforts to orient listed real estate toward social ends - for instance, through public co-financing - there is more than a little cause to assess these financial structures as further exacerbating the divide between insiders and outsiders to the knowledge- and asset-driven globalized urban economy.

Open Access This article is licensed under a Creative Commons Attribution 4.0 International License, which permits use, sharing, adaptation, distribution and reproduction in any medium or format, as long as you give appropriate credit to the original author(s) and the source, provide a link to the Creative Commons licence, and indicate if changes were made. The images or other third party material in this article are included in the article's Creative Commons licence, unless indicated otherwise in a credit line to the material. If material is not included in the article's Creative Commons licence and your intended use is not permitted by statutory regulation or exceeds the permitted use, you will need to obtain permission directly from the copyright holder. To view a copy of this licence, visit http://creativecommons.org/licen ses/by/4.0/. 


\section{References}

Aalbers MB (2008) The financialization of home and the mortgage market crisis. Compet Chang 12(2):148-166. https://doi.org/10.1179/102452908X289802

Aalbers MB (2015) The potential for financialization. Dialogues in Human Geography 5(2):214-219. https://doi.org/10.1177/2043820615588158

Aalbers MB (2017) The variegated financialization of housing: THE VARIEGATED FINANCIALIZATION OF HOUSING. Int J Urban Reg Res 41(4):542-554. https://doi.org/10.1111/1468-2427. 12522

Aalbers MB, Christophers B (2014) Centring housing in political economy. Hous Theory Soc 31(4):373394. https://doi.org/10.1080/14036096.2014.947082

Aimco (2020) Investor presentation. https://s1.q4cdn.com/176956323/files/doc_presentations/2020/11/ AIR_November_Presentation_Final.pdf. Accessed 7 Dec 2020

Alter A, Dokko J, Seneviratne D (2018) House price synchronicity, banking integration, and global financial conditions. WP/18/250. Working Paper. International Monetary Fund

Anderson B (2019) SFR investors dispute resident lawsuits that claim bad management practices. National Real Estate Investor. February 25, 2019. https://www.nreionline.com/single-familyrentals/sfr-investors-dispute-resident-lawsuits-claim-bad-management-practices

Arrighi G (1994) The Long Twentieth Century: Money, Power, and the Origins of Our Times. Verso, London

Ascott Residential Trust (2020) REITs Symposium 2020 Online Edition. September 19. https://inves tor.ascottresidencetrust.com/newsroom/20200918_174403_HMN_IBBKMKYUICE6HMU8.1. pdf. Accessed 10 Dec 2020

August M (2020) The financialization of Canadian multi-family rental housing: from trailer to tower. J Urban Aff 42(7):975-997. https://doi.org/10.1080/07352166.2019.1705846

August M, Walks A (2018) Gentrification, suburban decline, and the financialization of multi-family rental housing: The case of Toronto. Geoforum 89:124-36. https://doi.org/10.1016/j.geoforum. 2017.04.011

Aveline-Dubach N (2020) The financialization of rental housing in Tokyo. Land Use Policy, January, 104463. https://doi.org/10.1016/j.landusepol.2020.104463

Bloomberg (2020) China takes first steps toward \$3 trillion REIT market. Bloomberg.Com, June 2, 2020. https://www.bloomberg.com/news/articles/2020-06-02/china-takes-first-steps-towardlaunching-3-trillion-reit-market

Brumer L (2019) The affordable housing crisis and investor opportunity. Motley Fool. September 18, 2019. https://www.fool.com/millionacres/real-estate-market/articles/affordable-housing-crisisand-opportunity-it-presents-real-estate-investors/

Caballero RJ, Farhi E, Gourinchas P-O (2017) The safe assets shortage conundrum. Journal of Economic Perspectives 31(3):29-46. https://doi.org/10.1257/jep.31.3.29

CBRE (2019) Capital flows into European multifamily housing. CBRE Research. https://www.cbre. de/en/research/Capital-Flows-into-European-Multifamily-Housing. Accessed 28 Oct 2020

Chong F (2019) China: the year of the C-REIT? Real Assets. October 2019. https://realassets.ipe.com/ china-the-year-of-the-c-reit/10033322.article. Accessed 10 Dec 2020

Christophers B (2015) The limits to financialization. Dialogues in Human Geography 5(2):183-200. https://doi.org/10.1177/2043820615588153

Civitas Housing PLC (2019) Half year report. Civitas Housing. https://www.civitassocialhousing. com/media/1529/csh-plc-hy19_web.pdf. Accessed 7 Jun 2021

Corcoran J (2020) Residential REITs: a potential bright spot in challenging times. Invesco Blog (blog). May 1, 2020. https://www.blog.invesco.us.com/residential-reits-a-potential-bright-spotin-challenging-times/

Engelen E (2008) The case for financialization. Compet Chang 12(2):111-119. https://doi.org/10. $1179 / 102452908 X 289776$

EPRA (2017) German residential champion Vonovia clears the mist over organic growth model. EPRA Newsletter, no. 59 (May). https://magazine.epra.com/wp-content/uploads/2018/06/EPRAIndustry-Newsletter-59-May2017.pdf. Accessed 3 Dec 2020

Epstein G (2005) Financialization and the World Economy. Northampton: Edward Elgar

Equity Residential (2020) Investor Update. Accessed 7 Dec 2020 
FMO (2019) SUN communities took homes according to yet another lawsuit. Federation of Manufactured Home Owners of Florida. December 1, 2019. https://fmo.org/blog/id/155

Fuller GW (2016) The great debt transformation: households, financialization, and policy responses. Palgrave Macmillan, New York

Fuller GW (2019) The Political Economy of Housing Financialization Comparative Political Economy. Agenda Publishing, Newcastle upon Tyne

Gecina (2019) Building the future. Presented at the Investor Day 2019, Paris, September 25. https:// www.gecina.fr/sites/default/files/2019-09/investor-day_vdef_site_internet.pdf. Accessed 8 Dec 2020

Greenspan A (2000) Technological innovation and the economy -- April 5, 2000. FRB Remarks, White House Conference on the New Economy, April 5. https://www.federalreserve.gov/board docs/speeches/2000/20000405.htm. Accessed 3 Jun 2021

Hellwig MF (2009) Systemic risk in the financial sector: an analysis of the subprime-mortgage financial crisis. De Economist 157(2):129-207. https://doi.org/10.1007/s10645-009-9110-0

Hilbers P (2020) Property price dynamics: domestic and international drivers. 64. Committee on the Global Financial System. Bank for International Settlements. https://www.bis.org/publ/cgfs64.pdf. Accessed 11 Dec 2020

Huang Y (2010) An investigation into the use of REITs to finance affordable housing in Mainland China. PhD Dissertation, Cambridge MA: Massachusetts Institute of Technology. https://dspace.mit.edu/ handle/1721.1/59741. Accessed 10 Dec 2020

Hueang J (2019) A study of using REITs as an alternative way of financing affordable housing in Chinese major cities, based on the context of Nanjing. PhD Dissertation, Glasgow: University of Glasgow. http://theses.gla.ac.uk/41096/7/2019huangphd.pdf. Accessed 10 Dec 2020

Irish Residential Property REIT (2020) Building communities and creating value. EPRA 2020 Conference, September 10. https://investorrelations.iresreit.ie/sites/ires-ir/files/2020-09/epra-conferencepresentation.pdf. Accessed 8 Dec 2020

Jensen J (2018) Morningstar: five cities determine major apartment REIT performance. HousingWire (blog). May 23, 2018. https://www.housingwire.com/articles/43452-morningstar-five-cities-deter mine-major-apartment-reit-performance/

JLL (2020) Interactive flows map I the investor. Jones Lang LaSalle Incorporated. https://www.theinvestor.j11/interactive-flows-map/. Accessed 10 Dec 2020

Jones K, Andreas K, Schuetze A (2016) UPDATE 2-Vonovia's hostile bid for Deutsche Wohnen crumbles. Reuters, February 10, 2016. https://de.reuters.com/article/deutsche-wohnen-ma-vonoviaidUKL8N15P32M

Kaplan T (2014) Jury awards record $\$ 111$ million to trailer park residents. The Mercury News (blog). April 20, 2014. https://www.mercurynews.com/2014/04/20/jury-awards-record-111-million-to-trail er-park-residents/

Korthals Altes WK (2019) Annington versus Deutsche Annington: private equity and housing in the Anglo-Saxon and Rhenish contexts. Hous Theory Soc 36(2):228-253. https://doi.org/10.1080/ 14036096.2018.1479300

Lee R, Clark GL, Pollard JS, Leyshon A (2009) The remit of financial geographY-before and after the crisis. Journal of Economic Geography 9(5):723-747. https://doi.org/10.1093/jeg/lbp035

Lewis M (2011) The Big Short : Inside the Doomsday Machine. W.W. Norton, New York

Lima V (2020) The financialization of rental housing: Evictions and rent regulation. Cities 105:102787. https://doi.org/10.1016/j.cities.2020.102787

Lin YC, Lee CL, Newell G (2019) The significance of residential REITs in Japan as an institutionalised property sector. Journal of Property Investment \& Finance 37(4):363-379. https://doi.org/10.1108/ JPIF-03-2019-0036

Liu A, Shim I, Sushko V (2020) Cross-border commercial real estate investment in Asia-Pacific. Bank for International Settlements

Lumsden G (2018) Multifamily housing REIT scraps flotation, returns money. Citywire. November 7, 2018. https://citywire.co.uk/investment-trust-insider/news/multifamily-housing-reit-scraps-flotationreturns-money/a1173047

Magdoff H, Sweezy P (1987) Stagnation and the financial explosion. Monthly Review Press, New York

Martin R (2002) Financialization of daily life. Temple University Press, Philadelphia

Marzuki MJ, Newell G (2019) The evolution of Belgium REITs. Journal of Property Investment \& Finance 37(4):345-362. https://doi.org/10.1108/JPIF-03-2019-0029 
McDonald PR (2020) Is billionaire landlord Sam Zell the quintessential corporate vulture? CityWatch Los Angeles. June 22, 2020. https://www.citywatchla.com/index.php/cw/los-angeles/19965-is-billi onaire-landlord-sam-zell-the-quintessential-corporate-vulture

Mian A, Sufi A (2014) House of debt: how they (and you) caused the great recession, and how we can prevent it from happening again. The University of Chicago Press, Chicago

Mian A, Sufi A (2018) Finance and business cycles: the credit-driven household demand channel. Journal of Economic Perspectives 32(3):31-58. https://doi.org/10.1257/jep.32.3.31

Morwa R (2020) Why residential REITs are set to soar. Seeking Alpha. August 29, 2020. https://seeki ngalpha.com/article/4371226-why-residential-reits-are-set-to-soar

Nareit (2020) U.S. REIT Industry Equity Market Cap. Nareit. 2020. https://www.reit.com/data-research/ reit-market-data/us-reit-industry-equity-market-cap

NMHC (2020) 2018 owner list. National Multifamily Housing Council. 2020. https://www.nmhc.org/ research-insight/the-nmhc-50/top-50-lists/2018-owner-list/. Accessed 10 Dec 2020

Piketty T (2020) Capital and ideology. Translated by Arthur Goldhammer. Cambridge, Massachusetts ; London, England: Harvard University Press

Roberts M, Tostevin P (2020) Global living - 2020. World Research. Savills. https://pdf.euro.savills.co. uk/global-research/savills-global-living-2020.pdf. Accessed 4 Dec 2020

Romainville A (2017) The financialization of housing production in Brussels: the financialization of housing production in Brussels. Int J Urban Reg Res 41(4):623-641. https://doi.org/10.1111/14682427.12517

Semuels A (2019) When Wall Street is your landlord. The Atlantic, February 13, 2019. https://www. theatlantic.com/technology/archive/2019/02/single-family-landlords-wall-street/582394/. Accessed 8 Dec 2020

Stachen J (2020) EMEA Market Outlook 2020 Midyear Review. CBRE Research. https://www.cbre.it/en/ research-and-reports/EMEA-Real-Estate-Market-Outlook-2020-Multifamily. Accessed 8 Dec 2020

Stannard M (2018) REITs as a force for good. Grant Thornton UK LLP. June 13, 2018. https://www.grant thornton.co.uk/en/insights/reits-a-force-for-good/

Strauss LC (2020) Residential REITs will weather the coronavirus crisis better than malls. Here's why. Barron's. March 28, 2020. https://www.barrons.com/articles/residential-reits-will-weather-the-crisis-better-than-malls-51585402200

UDR (2020) Investor presentation. November. https://s27.q4cdn.com/542031646/files/doc_presentations/ 2020/11/1/Investor-Presentation.pdf. Accessed 7 Jun 2021

UN Human Rights Council (2017) Report of the special rapporteur on adequate housing as a component of the right to an adequate standard of living, and on the right to non-discrimination in this context. A/HRC/34/51. United Nations Human Rights Council. http://unhousingrapp.org/user/pages/04. resources/Thematic-Report-3-The-Financialization-of-Housing.pdf. Accessed 22 May 2021

Vonovia (2020a) Shareholder structure. Vonovia Interim Statement Q3 2020. September 30, 2020. https://reports.vonovia.de/2020/q3/en/business-development/vonovia-se-in-the-capital-market/share holder-structure.html

Vonovia (2020b) 9M 2020 Investor presentation. November 4. https://investoren.vonovia.de/download/ companies/deutscheanningtonimmo/Presentations/2020_11_04_Vonovia_Q32020.pdf

Waldron R (2018) Capitalizing on the state: the political economy of real estate investment trusts and the 'resolution' of the crisis. Geoforum 90(March):206-218. https://doi.org/10.1016/j.geoforum.2018. 02.014

Wendt A (1998) On constitution and causation in international relations. Rev Int Stud 24(5):101-118. https://doi.org/10.1017/S0260210598001028

Wijburg G, Aalbers MB, Heeg S (2018) The Financialisation of Rental Housing 2.0: releasing housing into the privatised mainstream of capital accumulation. Antipode. 50(4):1098-1119. https://doi.org/ 10.1111/anti.12382

Wotapka D (2012) Advocates take aim at equity residential. Wall Street Journal, July 31, 2012, sec. Real Estate. https://online.wsj.com/article/SB10000872396390444130304577561312886228138.html

Yuen C (2016) Residents protest as link REIT cancels meeting about rent hikes, outsourcing. Hong Kong Free Press HKFP. May 6, 2016. https://hongkongfp.com/2016/05/06/residents-protest-link-reitcancels-meeting-rent-hikes-outsourcing/ 